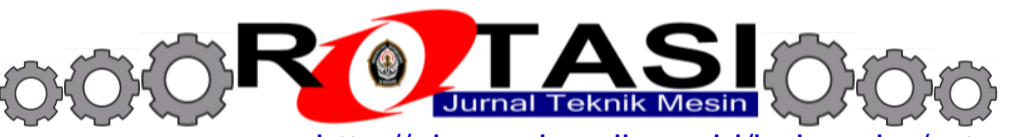

Available online at Website http://ejournal.undip.ac.id/index.php/rotasi

\title{
ANALISIS CFD HIDRODINAMIKA SLIDER BEARING DENGAN PERMUKAAN HETERO SLIP/NO-SLIP DENGAN/TANPA RECESS
}

\author{
*M. Tauviqirrahman ${ }^{a}$, S. Hermawan ${ }^{b}$ \\ aDosen Jurusan Teknik Mesin, Fakultas Teknik, Universitas Diponegoro \\ bAlumni Jurusan Teknik Mesin, Fakultas Teknik, Universitas Diponegoro \\ J1. Prof. Sudharto, SH., Tembalang-Semarang 50275, Telp. +62247460059 \\ *E-mail: mtauviq99@gmail.com
}

\begin{abstract}
ABSTRAK
Dewasa ini, industri dihadapkan pada tekanan untuk mengurangi konsumsi energi dan memperpanjang umur komponen dalam usaha untuk mengurangi biaya produksi dan dampak lingkungan. Sudah umum diketahui bahwa permukaan slip pada slider bearing dapat memperkecil gaya gesek sekaligus meningkatkan daya dukung beban. Selain itu, pemberian recess pada permukaan juga dapat meningkatkan performansi pelumasan. Dalam tulisan ini, analisis CFD hidrodinamika pada slider bearing dilakukan untuk memperoleh performansi pelumasan yang efektif. Dua bentuk recess (persegi dan trapesium) dan area permukaan slip/no-slip dibandingkan. Hasil simulasi menunjukkan bahwa pemberian slip dengan desain area tertentu pada bearing memberikan hasil performansi yang lebih baik dibandingkan kondisi no-slip. Selain itu, pemberian recess berbentuk trapesium yang dikombinasikan dengan slip terbukti menghasilkan daya dukung beban yang besar dan gesekan yang kecil.
\end{abstract}

Kata kunci: CFD (computational fluid dynamic), pelumasan, slip, recess.

\section{PENDAHULUAN}

Sejak zaman dulu, aktivitas manusia selalu erat kaitannya dengan gesekan, ketahanan untuk bergeser. Dalam banyak hal, gaya gesek sangat bermanfaat bagi manusia seperti pengereman mobil. Namun dalam banyak hal lainnya, aktivitas manusia banyak yang terhambat akibat gaya gesek ini. Bagaimana cara meminimalkan gesekan menjadi salah satu dasar permasalahan utama teknologi hingga saat ini. Oleh karena itu, tribologi berperan sangat penting dalam meningkatkan suatu performansi alat-alat industri dimana menyangkut ketahanan terhadap force seperti gaya gesek [1]. Salah satu komponen yang berkaitan erat dengan industri adalah slider bearing, dimana meliputi komponen yang bergerak dan salah satu tantangan dalam desainnya adalah membatasi gesekan yang terjadi antara komponen-komponen yang mengalami kontak [2]. Untuk mengurangi gesekan antar permukaan yang ada dalam slider bearing, maka dibutuhkan pelumas.

Dekade ini telah ditemukan bahwa slip terjadi pada aliran baik pada skala mikro maupun makro. Slip terbukti dapat mengurangi gaya gesek [3-7], sehingga dapat dimanfaatkan untuk membuat sistem slider bearing dengan gaya gesek rendah. Akan tetapi jika slip dirancang secara seragam, slip cenderung mengurangi daya dukung pelumasan dalam kontak terlumasi. Selain slip, tipe tekstur baik yang berbentuk sigle texture (recess/pocket) maupun multiple texture (partial texturing dan full texturing) yang diterapkan pada salah satu permukaan slider bearing ternyata juga berpengaruh pada gaya gesek dan daya dukung pelumasan. Berbagai penelitian juga telah dilakukan terkait dengan tekstur dan segala varasianya dengan tujuan memaksimalkan performansi pelumasan. Analisis teoritik pada sistem dengan permukaan bertekstur pada umumnya dilakukan dengan menggunakan persamaan Reynolds [8-12]. Sebagai misal, penelitian terkini yang dilakukan oleh Tauviqirrahman, dkk [12]. Mereka menunjukkan bahwa partial texturing memberikan peningkatan yang lebih baik daripada full texturing. Namun, dibandingkan permukaan flat dengan slip kompleks, permukaan tekstur sebagian masih kurang efisien untuk meningkatkan daya dukung beban, bahkan jika konfigurasi tekstur ini dikombinasikan dengan kondisi slip. Maka diperlukan pengaturan pola permukaan slip/no-slip dan tekstur pada permukaan bearing. Meskipun demikian, seiring dengan meningkatnya masalah keteknikan dengan geometri yang komplek, persamaan Reynolds menjadi semakin kurang valid. Karena itu, aplikasi simulasi CFD (computational fluid dynamic) berdasar persamaan Navier-Stokes menjadi semakin popular dan cukup efektif kaitannya dengan penelitian aplikasi tekstur dalam bearing [13-16].

Meskipun demikian, dalam beberapa penelitian yang telah dipublikasikan, analisa performansi pelumasan pada bearing bertekstur (yang memiliki recess) hanya dilakukan dengan mengesampingkan fakta bahwa slip ada pada kontak. Selain itu, pemodelan recess hanya dilakukan dengan mengasumsikan bahwa lebar bearing tak terbatas (analisa 1 dimensi). Berdasarkan penelitian terbaru [17], pemodelan lebar bearing memiliki efek yang signifikan terhadap prediksi performansi pelumasan dengan slip. Dengan demikian diperlukan suatu penelitian tentang pengaruh permukaan heterogen slip/no-slip dan variasi bentuk recess dengan analisa CFD 2 dimensi sehingga diperoleh prediksi performansi pelumasan pada slider bearing yang lebih akurat. 


\section{METODOLOGI}

\subsection{Skema slider bearing}

Finite slider bearing dimodelkan dalam inclined pad bearing yang sederhana seperti pada Gambar 1, dimana dua permukaan berbentuk konvergen dengan sudut tertentu. Pada slider bearing ini ketebalan film atau ketinggian fluida memisahkan dua permukaan. Ketinggian fluida ini merupakan fungsi linier dari $x$ (Persamaan 1). Permukaan atas dilabelkan sebagai permukaan 1 yang merupakan permukaan yang diam. Sedangkan permukaan bawah dilabelkan dengan permukaan 2, yaitu permukaan yang bergerak dengan kecepatan $U_{1}$. Pada permukaan atas, ditambahkan recess dengan dua pola untuk diperbandingkan, yaitu pola trapezium dan pola persegi, seperti disajikan dalam Gambar 2. Daerah ini, dianggap sebagai daerah slip dan ditempatkan sejajar dengan ujung inlet fluida. Dan pada tiga sisi yang tersisa yaitu daerah no-slip. Efek yang diinginkan adalah fluida mengalir pertama melalui daerah slip dan kemudian keluar melalui daerah no-slip.

$$
h(x)=h_{1}-\frac{\left(h_{i}-h_{o}\right)}{L} x
$$

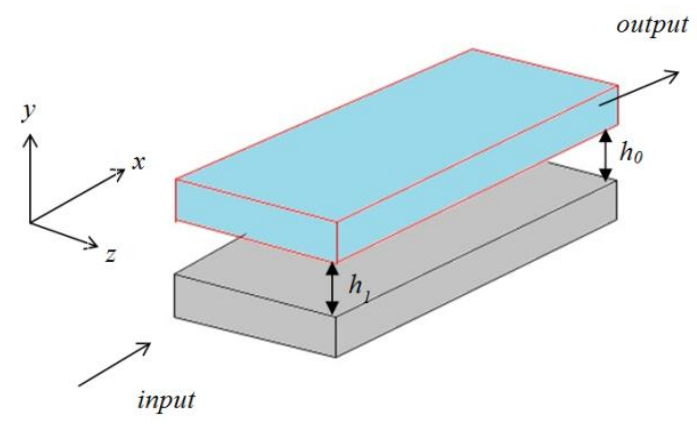

Gambar 1. Pandangan isometri skema model slider bearing kondisi no-slip.

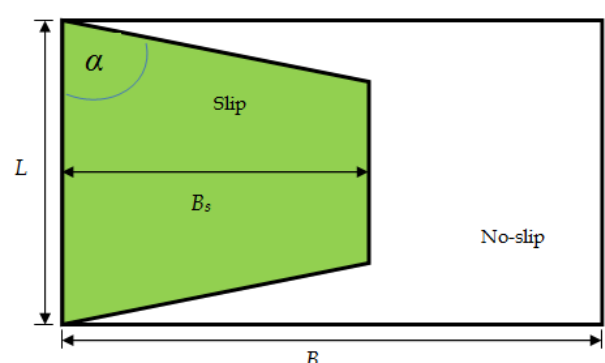

(a)

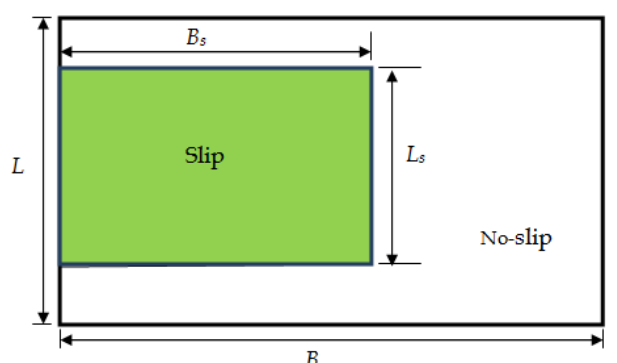

(b)

Gambar 2. Pandangan atas geometri slider bearing kondisi heteroslip dengan (a) pola trapesium, (b) pola persegi.

Untuk keseluruhan simulasi dalam penelitian, geometri yang digunakan adalah sebagai berikut:
Panjang bearing
$B=1 \mathrm{~mm}$
Lebar bearing
$L=1 \mathrm{~mm}$
Tinggi maksimum
$h_{l}=1 \mu \mathrm{m}$
Tinggi minimum
$h_{0}=1 \mu \mathrm{m}$
Panjang permukaan slip
$B_{s}=0.65 \mathrm{~mm}$
Lebar permukaan slip
$L_{s}=0.8 \mathrm{~mm}$
Panjang permukaan slip
Sudut permukaan slip

$$
B_{s}=0.7 \mathrm{~mm}
$$$$
\alpha=70^{\circ} \mathrm{mm}
$$

Untuk pola persegi

Untuk pola trapezium

\subsection{Kondisi Batas dan Prosedur Solusi}

Dalam penelitian ini, asumsi nilai tekanan pada sisi masuk dan keluar slider bearing diatur nol dan gradien kecepatan bernilai nol pada arah normal terhadap sliding. Pada permukaan yang bergerak, kondisi batas heteroslip diasumsikan untuk persamaan aliran, yaitu kecepatan dinilai konstan, sementara tekanan memiliki kondisi batas gradien nol. Kondisi batas yang digunakan pada kasus ini adalah sebagai berikut:
Kecepatan dinding bawah
$U_{l}=10 \mathrm{~m} / \mathrm{s}$
Bilangan Reynolds
$R e=10$ (aliran laminar) 
Massa jenis pelumas

Viskositas dinamis pelumas

$$
\begin{aligned}
\rho & =10^{3} \mathrm{~kg} / \mathrm{m}^{3} \\
\eta & =10^{-3} \mathrm{Pas}
\end{aligned}
$$

Dalam penelitian ini, empat kasus yang akan disimulasikan sebagai bentuk variasi slider bearing (lihat Tabel 2). Pelumasan yang terjadi akan dianalisa karakteristik hidrodinamiknya dengan menggunakan perangkat lunak komersil CFD (computational fluid dynamic). Tujuan yang ingin dicapai adalah apakah dengan mengkombinasikan slip dengan recess akan meningkatkan atau menurunkan performansi pelumasan dalam slider bearing. Untuk memodelkan slip, kode UDF (user-defined-function) dalam perangkat lunak komersial CFD dikembangkan berdasarkan persamaan Navier-slip. Kode ini selanjutkan dieksekusi agar bisa masuk dan dimanfaatkan dalam perangkat tersebut.

Tabel 2. Konfigurasi bearing yang digunakan

\begin{tabular}{ll}
\hline No & \multicolumn{1}{c}{ Konfigurasi bearing } \\
\hline 1 & Bearing dengan recess pola persegi \\
2 & Bearing dengan recess pola trapesium \\
3 & Bearing dengan kombinasi heteroslip dengan recess pola persegi \\
4 & Bearing dengan kombinasi heteroslip dengan recess pola trapesium \\
\hline
\end{tabular}

\section{HASIL DAN PEMBAHASAN}

\subsection{Validasi}

Hal pertama yang dilakukan dalam upaya menyelesaikan suatu permasalahan analisis adalah mencari suatu pembanding. Pembanding tersebut digunakan untuk melakukan suatu pengujian kelayakan hasil, yaitu dengan membandingkan hasil-hasilnya. Dari hasil validasi, diketahui hasil perhitungan ulang telah memenuhi syarat atau tidak. Klasifikasi memenuhi syarat jika hasil sudah mendekati dengan hasil perhitungan yang telah ada di beberapa literatur yang dijadikan acuan. Dalam penelitian ini, penelitian yang dijadikan acuan adalah hasil kerja Wu dkk [18] dimana mereka membuat pemodelan slider bearing dengan recess yang dikombinasikan dengan slip. Tabel 1 menyajikan validasi hasil simulasi (daya dukung beban (load support), $W$ ) seperti ditunjukkan pada Tabel 1. Dari Tabel 1 dapat diambil kesimpulan bahwa kode UDF yang dikembangkan dalam perangkat lunak komesial CFD terbukti sukses diaplikasikan dalam analisa hidrodinamika slider bearing. Selisih antara hasil analitik [18] dengan hasil numeric present study tidak lebih dari $5 \%$.

Tabel 1. Validasi daya dukung beban pada slider bearing

\begin{tabular}{lcc}
\hline \multirow{2}{*}{ Konfigurasi } & Ref [18] & Present Study \\
\cline { 2 - 3 } & W/W no-slip & W/W no-slip \\
\hline Heteroslip pola persegi & 2.28 & 2.18 \\
\hline
\end{tabular}

Keterangan: $W / W_{n o-s l i p}$ adalah rasio antara daya dukung beban pada slider bearing dengan slip dengan daya dukung pada slider bearing klasik (no-slip)

\subsection{Pengaruh slip dengan/tanpa recess}

Gambar 3-7 menyajikan hasil-hasil simulasi perangkat lunak CFD berupa daya dukung beban (load support), gaya gesekan (friction force), dan koefisien gesek (friction coefficient) dengan menggunakan berbagai konfigurasi slider bearing. Seperti tampak pada Gambar 3, variasi kedalaman recess, $D$ memiliki pengaruh yang cukup signifikan terhadap load support. Ada pola menarik yang bisa diamati dari Gambar 3 di bawah bahwa mengkombinasikan slip dengan recess pada slider bearing merupakan ide terbaik dalam hal perningkatan performansi load support baik itu dengan menggunakan pola area slip recess trapezium maupun persegi. Meskipun demikian, jika kedalaman recess $D$ diatur sama dengan nol yang berarti permukaan slider bearing nya dirancang flat tanpa recess, pelumasan mampu memberikan load support maksimum.

Seiring dengan meningkatnya kedalaman recess, load support menurun untuk kedua konfigurasi bearing dengan kombinasi slip dan recess. Bahkan pada kedalaman $D$ tertentu, nilai load support nya lebih rendah dibanding dengan performansi bearing yang hanya mengandalkan recess (tanpa slip). Dapat dilihat juga dari Gambar 3 ini bahwa pola slip dan recess trapesium memberikan load support yang lebih besar dibanding dengan pola slip dan recess peregi. Begitu juga untuk kasus bearing klasik (tanpa slip), secara umum recess dengan pola trapesium juga lebih tinggi dibandingkan dengan recess dengan pola persegi. Perlu dicatat pula bahwa ada nilai optimum untuk harga kedalaman recess baik itu untuk bentuk persegi maupun trapesium. Dengan $D_{\text {optimum }}$ ini, harga load support maksimum dapat dicapai. Selain itu, penemuan lainnya adalah bahwa slider bearing tanpa slip ketika recess tidak ada, load support nya mendekati nol yang berarti kegagalan bearing akibat pelumasan yang gagal akan terdeteksi. 


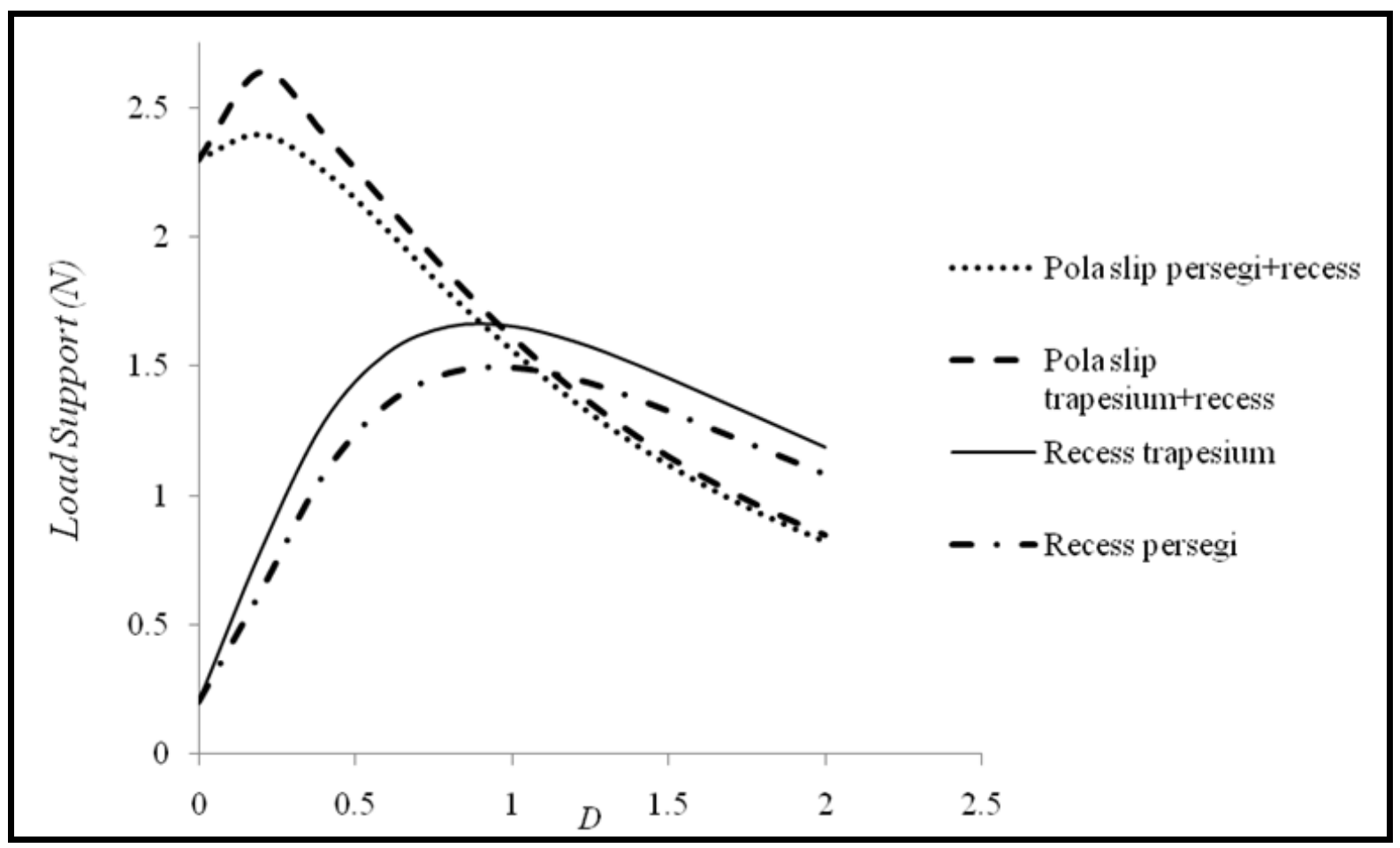

Gambar 3. Grafik perbandingan load support $(W)$ dengan kedalaman recess untuk konfigurasi no-slip (pola persegi dan pola trapesium) dengan recess, heteroslip untuk pola persegi dengan recess dan heteroslip untuk pola trapesium dengan recess.

Efek dari kedalaman recess dan friction force $(F)$ untuk slider bearing dengan slip maupun no-slip ditunjukkkan oleh Gambar 4. Grafik tersebut menunjukkan tren yang berbeda. Untuk kondisi slip dengan recess, friction force $(F)$ minimum pada saat kedalaman 0 dan meningkat sampai mencapai harga maksimum ketika kedalaman recess $D$ meningkat. Sedangkan untuk kondisi recess no-slip, friction force $(F)$ berharga maksimum ketika kedalaman recess nol kemudian semakin menurun saat kedalaman recess-nya meningkat.

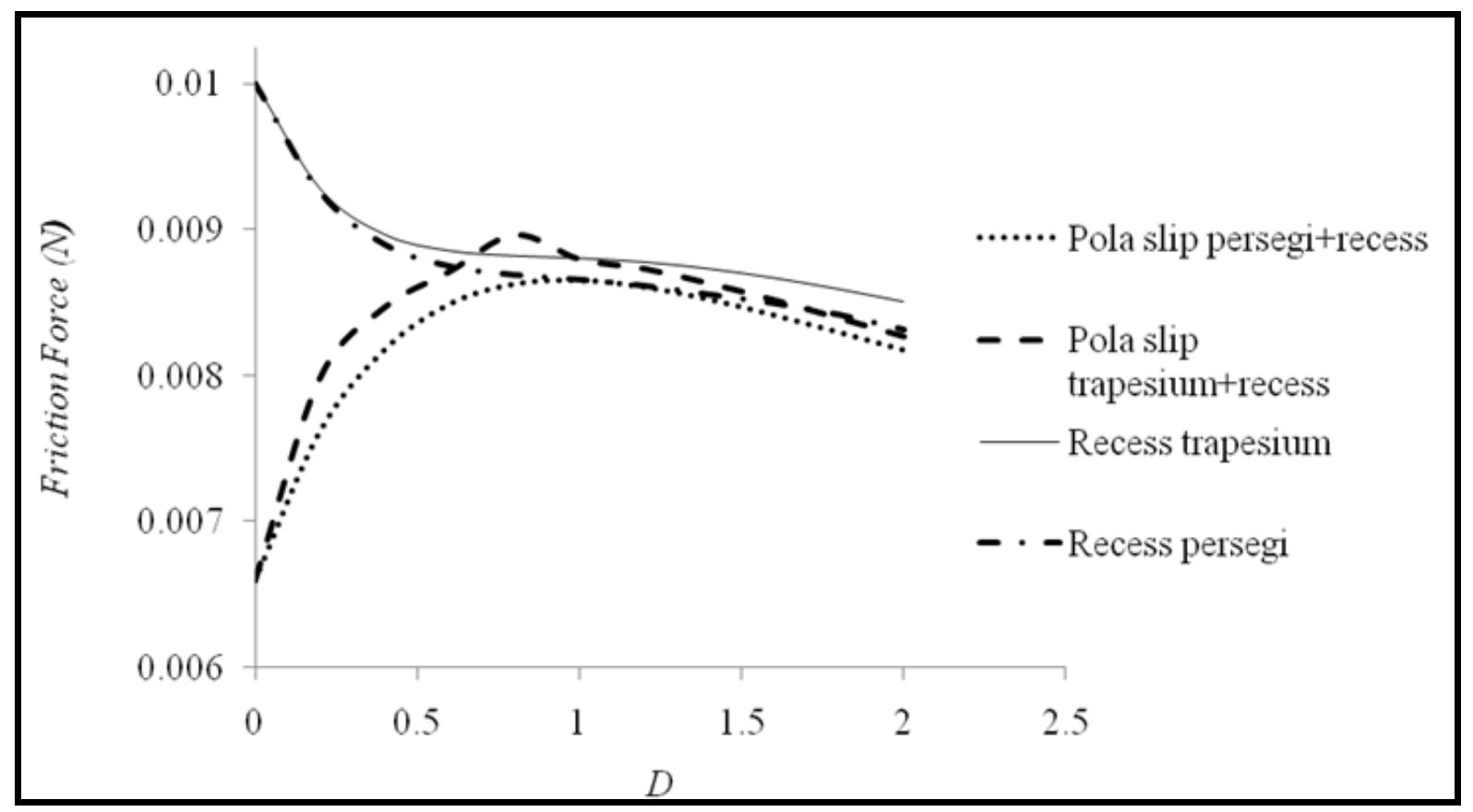

Gambar 4. Grafik perbandingan friction force $(F)$ dengan kedalaman recess untuk kasus no-slip (pola persegi dan pola trapesium) dengan recess, heteroslip untuk pola persegi dengan recess dan heteroslip untuk pola trapesium dengan 
Gambar 5 menunjukkan bahwa kenaikan load support $(W)$ tertinggi terjadi pada heteroslip pola trapesium dengan kedalaman recess $0.2 \mu \mathrm{m}$. Sedangkan Gambar 6 menunjukkan bahwa penurunan friction force maksimum dicapai oleh bearing dengan konfigurasi heteroslip pola trapesium dengan recess $0.8 \mu \mathrm{m}$. Hal ini karena heteroslip pola trapesium dengan recess mempunyai koefisien gesek yang paling rendah diantara ketiga konfigurasi lainnya seperti yang ditunjukkan pada Gambar 7.

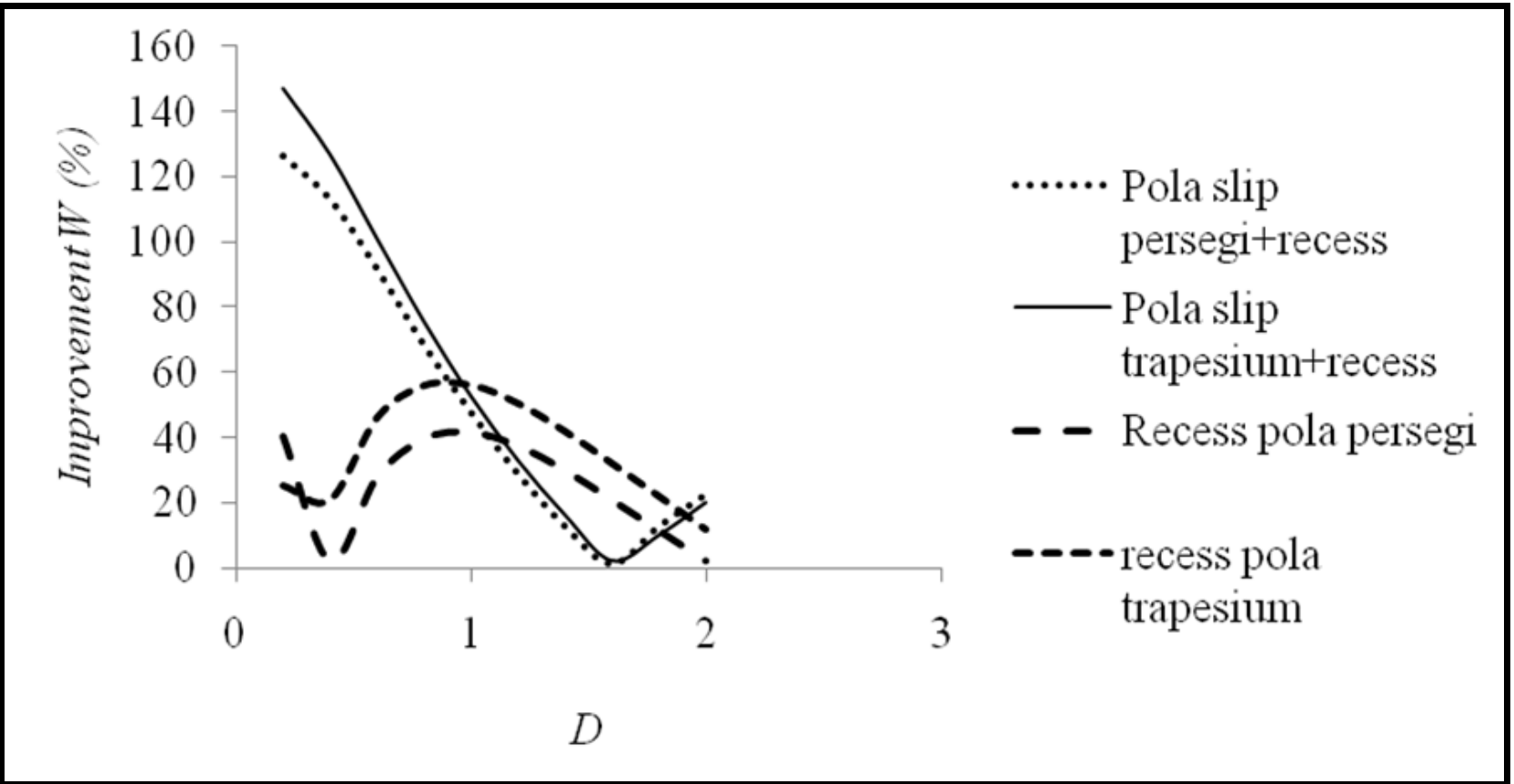

Gambar 5. Grafik perbandingan kenaikan load support $(W)$ untuk konfigurasi recess persegi, recess trapesium, heteroslip untuk pola persegi dengan recess dan heteroslip untuk pola trapesium dengan recess.

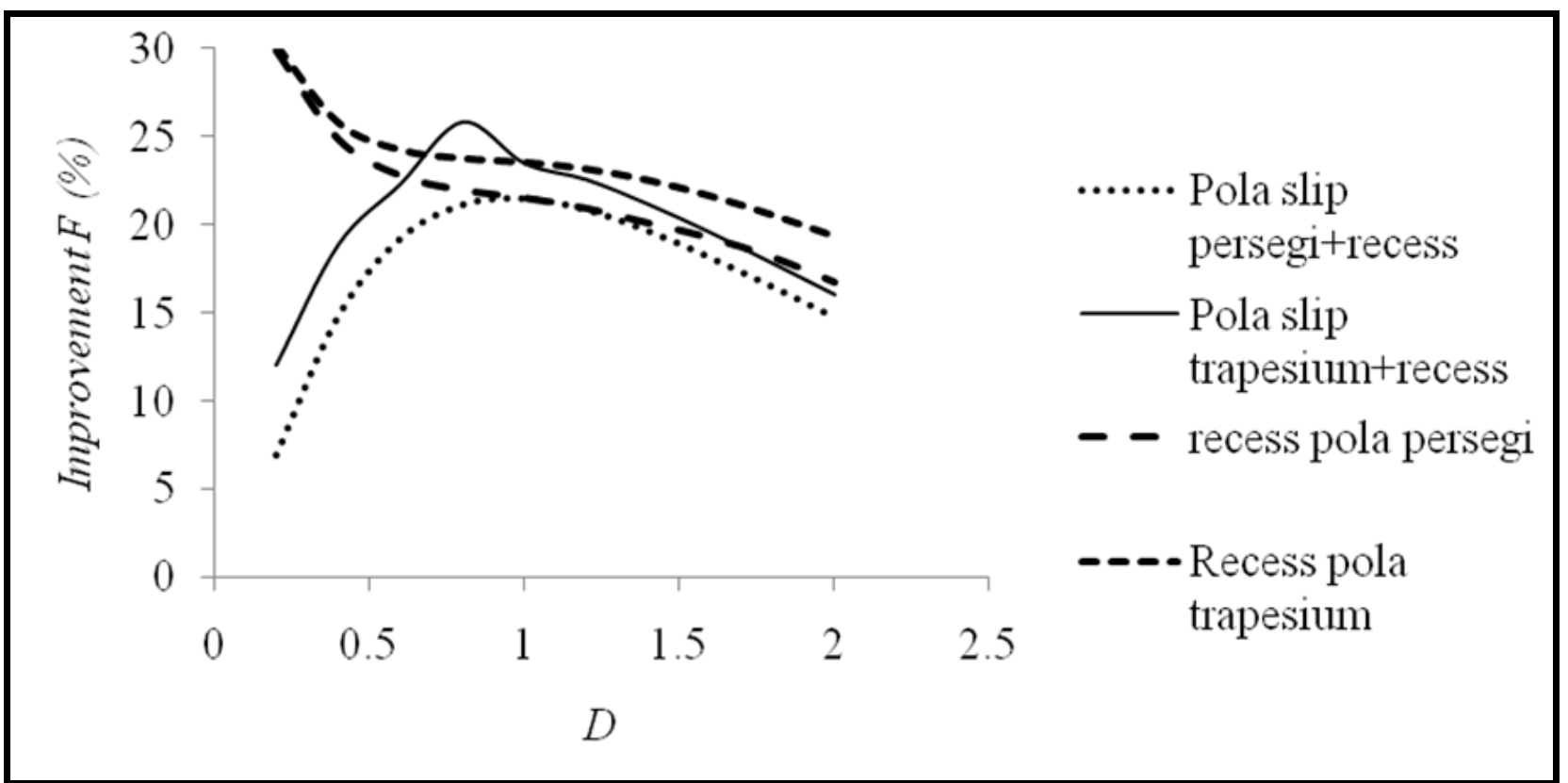

Gambar 6. Grafik perbandingan kenaikan friction force $(F)$ untuk konfigurasi recess persegi, recess trapesium, heteroslip untuk pola persegi dengan recess dan heteroslip untuk pola trapesium dengan recess. 


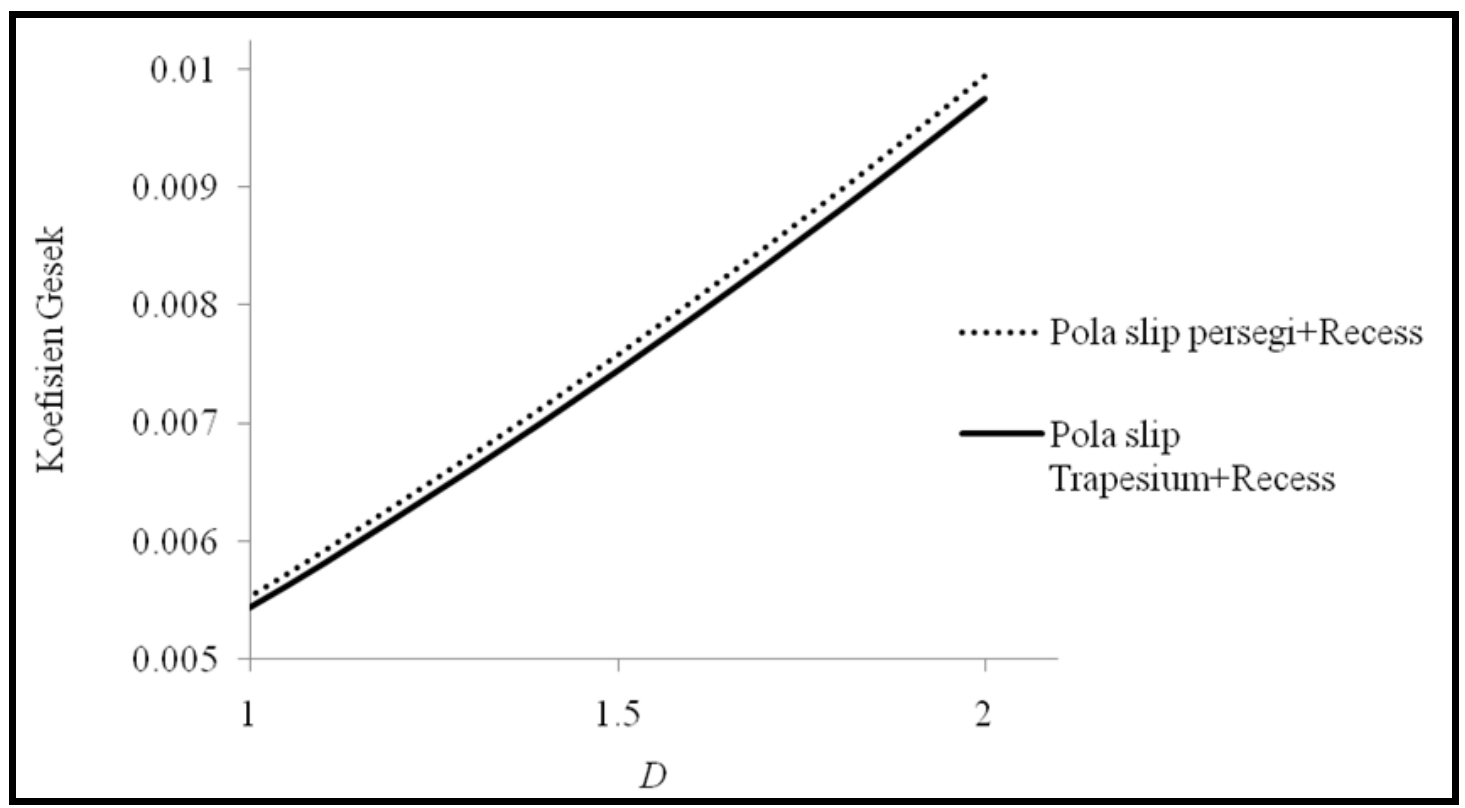

Gambar 7. Grafik perbandingan koefisien gesek untuk konfigurasi heteroslip untuk pola persegi recess dan heteroslip pola trapesium dengan recess.

\section{KESIMPULAN}

Kode UDF untuk memodelkan slip dalam perangkat lunak komersil CFD telah berhasil dilakukan. Berbagai konfigurasi slider bearing dibandingkan satu sama lain terkait dengan performansi pelumasan. Kesimpulan yang dapat diambil dari simulasi numerik slider bearing dengan variasi slip dan/atau recess adalah sebagai berikut:

1) Pengaruh permukaan heteroslip baik dengan pola slip persegi maupun trapesium terhadap performansi pelumasan akan menghasilkan nilai load support yang lebih besar sampai dengan dua kali lipat dibandingkan dengan kondisi no-slip.

2) Permukaan dengan penerapan kombinasi antara permukaan recess dan heteroslip akan menghasilkan nilai load support $(W)$ yang lebih besar dibandingkan dengan tanpa recess.

\section{DAFTAR PUSTAKA}

1. Bruzzone, A.A.G., Costa, H.L., Lonardo, P.M., dan Lucca, D.A., 2008, "Advances in engineered surfaces for functional performance", Manufacturing Technology 57, hlm. 750-769.

2. Hamrock, B.J., Schmid, S.R., dan Jacobson, B.O., 2004, Fundamental of Fluid Film Lubrication, Marcel Dekker Inc, New York, Amerika Serikat.

3. Pit, R., Hervet, H., dan Leger, L., 2000, "Direct experimental evidence of slip in hexadecane: Solid interfaces," Physical Review Letters 85, hlm. 980-983.

4. Zhu, Y.X., dan Granick, S., 2002, "Limits of the hydrodynamic no-slip boundary condition," Physical Review Letters 88, 106102.

5. Tretheway, D.C., dan Meinhart, C.D., 2002, "Apparent fluid slip at hydrophobic microchannel walls," Physic of Fluids 14, hlm. L9-12.

6. Choi, C.H., Westin, K.J.A., dan Breuer, K.S., 2003, “Apparent slip flows in hydrophilic and hydrophobic microchannels," Physic of Fluids 15, hlm. 2897-2902.

7. Cottin-Bizonne, C., Cross, B., Steinberger, A., dan Charlaix, E., 2005, "Boundary slip on smooth hydrophobic surfaces: intrinsic effects and possible artifacts," Physical Review Letters 94, 056102.

8. Kligerman, Y., Etsion, I., dan Shinkarenko, A., 2005, "Improving tribological performance of piston rings by partial surface texturing," ASME Journal of Tribology 127, hlm. 632-638.

9. Fowell, M., Olver, A.V., Gosman, A.D., Spikes, H.A., dan Pegg, I., 2007, "Entrainment and inlet suction: two mechanisms of hydrodynamic lubrication in textured bearings," ASME Journal of Tribology 129, hlm. 337-347.

10. Rahmani, R., Shirvani, A., dan Shirvani, H., 2007, "Optimization of partially textured parallel thrust bearings with square-shaped micro dimple," STLE Tribology Transactions 50, hlm. 401-406.

11. Pascovici, M.D., Cicone, T., Fillon, M., dan Dobrica MB, 2009, “Analytical investigation of a partially textured parallel slider," Proceeding of Instituions of Mechanical Engineers, Part J: Journal of Engineering Tribology 223, hlm. 151-158.

12. Tauviqirrahman, M., Ismail, R., Jamari, J., dan Schipper, D.J., 2012, "A study of surface texturing and boundary slip on improving the load support of lubricated parallel sliding contacts,” Acta Mechanica 224, hlm. 365-381. 
13. Sahlin, F., Glavatskih, S.B., Almqvist, T., dan Larsson, R., 2005, "Two-dimensional CFD-analysis of micropatterned surfaces in hydrodynamic lubrication," ASME Journal of Tribology 127, hlm. 96-102.

14. Brajdic-Mitidieri, P., Gosman, A.D., Loannides, E., dan Spikes, H.A., 2005, "CFD analysis of a low friction pocketed pad bearing," ASME Journal of Tribology 127, hlm. 803-812.

15. Han, J., Fang, L., Sun, J., dan Ge, S., 2010, "Hydrodynamic lubrication of microdimple textured surface using three-dimensional CFD," STLE Tribology Transactions 53, hlm. 860-870.

16. Shi, X., dan Ni, T., 2011, "Effects of groove textures on fully lubricated sliding with cavitation," Tribology International 44, hlm. 2022-2028.

17. Tauviqirrahman, M., Ismail, R., Jamari, dan Schipper, D.J., 2013, "Optimization of the complex slip surface and its effect on the hydrodynamic performance of two-dimensional lubricated contacts," Computers and Fluids 79, hlm. 27-43.

18. Wu, C.W., Ma, G.J., dan Zhou, P., 2007, "Hydrodynamic of slip wedge and optimization of surface slip proprerty", Science in China Series 50, hlm. 321-330. 